\title{
Interleukin-1 receptor antagonist expression is inversely associated with outcomes of hepatitis B-related acute-on-chronic liver failure
}

\author{
JINGLAN LAI ${ }^{1,2}$, YUMING LIU ${ }^{2}$, CHEN PAN $^{2}$, CHUN LIN $^{2}$, FANG SUN $^{2}$, \\ ZUXIONG HUANG $^{2}$, YONG LIN ${ }^{2}$, RUI ZHOU ${ }^{2}$, YUANBAO LIN ${ }^{2}$ and YUANPING ZHOU ${ }^{1}$ \\ ${ }^{1}$ Department of Infectious Diseases, Nanfang Hospital, Southern Medical University, Guangzhou, \\ Guangdong 510515; ${ }^{2}$ Department of Infectious Disease, Infectious Disease Hospital of Fuzhou, \\ Meng Chao Hepatobiliary Hospital, Fujian Medical University, Fuzhou, Fujian 350025, P.R. China
}

Received October 14, 2015; Accepted January 20, 2017

DOI: $10.3892 / \mathrm{etm} .2017 .4361$

\begin{abstract}
Interleukin-1 receptor antagonist (IL-1ra) is a naturally occurring anti-inflammatory antagonist of the proinflammatory cytokine IL-1, a critical factor in many inflammatory diseases. The aim of the present study was to investigate the role of IL-1ra in hepatitis B-related acute-on-chronic liver failure (HB-ACLF). Serum cytokine concentrations were measured using a Q-Plex array in 31 patients with HB-ACLF, 28 patients with acute hepatitis B (AHB), 31 patients with chronic hepatitis B (CHB) and 15 healthy control patients (HCs). Additionally, peripheral blood mononuclear cells (PBMCs) from patients with HB-ACLF were incubated with PBS or lipopolysaccharide and/or different concentrations of recombinant human IL-1ra (rhIL-1ra) in vitro. Cytokines in the supernatant were measured using a Q-Plex array. The median serum IL-1ra level in patients with HB-ACLF was $186.46(350.22) \mathrm{pg} / \mathrm{ml}$, which was significantly higher than all other groups (AHB, $\mathrm{P}=0.012$; $\mathrm{CHB}, \mathrm{P}<0.001$; HCs, $\mathrm{P}<0.001)$. However, the ratio of IL-1ra/IL-1 $\beta$ was significantly lower in the HB-ACLF group compared with the AHB group $(\mathrm{P}=0.048)$. Median serum IL-1ra levels in patients with AHB were also significantly increased compared with those in the CHB $(\mathrm{P}<0.001)$ and $\mathrm{HC}(\mathrm{P}<0.001)$ groups. Patients who succumbed to mortality within 3 months of the study were found to have significantly lower IL-1ra concentrations $(\mathrm{P}=0.02)$ and $\mathrm{IL}-1 \mathrm{ra} / \mathrm{IL}-1 \beta$ ratios $(\mathrm{P}=0.007)$ compared with surviving patients with HB-ACLF. Furthermore, serum IL-1ra concentrations were negatively associated with the Model for End-stage Liver Disease score $(r=-0.870 ; \mathrm{P}<0.001)$. Cytokine
\end{abstract}

Correspondence to: Professor Yuanping Zhou, Department of Infectious Diseases, Nanfang Hospital, Southern Medical University, 1838 North Guangzhou Avenue, Guangzhou, Guangdong 510515, P.R. China

E-mail: yuanpingzhou@163.com

Key words: interleukin-1 antagonist receptor, acute-on-chronic liver failure, chronic hepatitis B, Q-Plex array, peripheral blood mononuclear cell secretion by PBMCs in vitro was significantly inhibited in a dose-dependent manner by rhIL-1ra (125-500 ng/ml; all $\mathrm{P}<0.05)$. These results suggest that IL-1ra is associated with the development of liver inflammation, which is reduced in patients with HB-ACLF and inversely associated with disease severity.

\section{Introduction}

Hepatitis B virus (HBV) infection represents a global health problem with $\sim 50$ million patients suffering from chronic hepatitis B (CHB) infection worldwide (1). Each year $\sim 1$ million patients die due to cirrhosis and hepatocellular liver failure as a result of HBV infection (2). Acute-on-chronic liver failure (ACLF) is an acute deterioration of liver function in patients with chronic liver disease, which manifests as coagulopathy and severe jaundice, and is typically complicated within 4 weeks by ascites and/or encephalopathy (3). ACLF is characterized by its rapid progression and high mortality of $50-90 \%$ (3).

Interleukin (IL)-1 serves a crucial role in the immune response and inflammation and IL-1 receptor antagonist (ra), the naturally-occurring anti-inflammatory antagonist of IL-1, has also been established to be associated with various inflammatory and autoimmune disorders (4). An imbalance of IL-1ra and IL-1 results in the progression of various diseases (5). Although the complete pathophysiology of ACLF is not yet fully understood, uncontrolled hepatic immunoactivation, in particular the disorder of cytokines is thought to be the primary underlying pathological mechanism (6). In China, $>96 \%$ of ACLF cases are associated with HBV (7). The underlying mechanisms of HBV-induced immunopathological damage leading to liver failure remain unclear; therefore, investigating the changes in cytokine expression patterns in patients with HB-ACLF may facilitate the understanding of this underlying pathogenesis.

The present study was designed to analyze whether IL-1ra is associated with the progression of HBV-related ACLF (HB-ACLF). Healthy individuals and patients with acute HBV (AHB) or CHB were selected as controls and for comparison. Serum concentrations of IL-1ra and other cytokines [IL-1 $\beta$, IL-4, IL-6, interferon (IFN)- $\gamma$, IL-10, and tumor necrosis factor 
(TNF)- $\alpha]$ were measured. The association between serum IL-1ra and the prognosis of HB-ACLF was also assessed, as well as the association of IL-1ra with other cytokines in vitro.

\section{Materials and methods}

Study subjects. A total of 31 patients with ACLF, 28 patients with $\mathrm{AHB}$, and 31 patients with $\mathrm{CHB}$ who were admitted to the Infectious Disease Hospital of Fujian Medical University (Fuzhou, China) between November 2013 and January 2015 were enrolled in the present study. Additionally, 15 healthy volunteers were enrolled as healthy controls (HC). The patients were aged between 19 and 48 years (median=28) and consisted of 86 males and 19 females. Patient demographics are displayed in Table I and were well balanced across groups. None of the patients had received antiviral treatment or plasma exchange in the 6 months prior to the study. A total of $10 \mathrm{ml}$ blood was harvested from each patient with HB-ACLF upon admission. Patients with HB-ACLF received comprehensive liver-protecting treatment with human albumin, L-ornithine L-aspartate injection and polyene phosphatidylcholine injection on the day of admission prior to blood sampling and did not receive any treatement prior to admission. AHB and CHB were diagnosed in accordance with the diagnostic criteria as previously described (8). Briefly, the criteria for AHB was HBV surface antigen ( $\mathrm{HBsAg}$ )-negative conversion within 6 months of the initial onset of symptoms resulting from HBV infection. The diagnosis of CHB was based on a history of serum HBsAg positivity $>6$ months, serum alanine aminotransferase (ALT) levels greater than the upper limit of the normal level, serum total bilirubin (TBIL) $<10$ times the normal level $(171 \mu \mathrm{mol} / \mathrm{l})$, and prothrombin time activity (PTA) $>40 \%$. HB-ACLF was diagnosed according to the criteria recommended by The $19^{\text {th }}$ Conference of the Asian Pacific Association for the Study of the Liver in 2009 (9).

Patients with any of the following conditions were excluded from the present study: Concurrent hepatitis A, C, D, or E virus, human immunodeficiency virus (HIV) infections, other liver diseases (such as Wilson's disease, autoimmune hepatitis, primary biliary cirrhosis, alcoholic liver disease), bacterial infection, diabetes mellitus or tumor.

The HC group was recruited from staff and students at the Infectious Disease Hospital of Fujian Medical University. The Model for End-stage Liver Disease (MELD) score was calculated using the following formula: $3.8 \times \log$ [bilirubin $(\mathrm{mg} / \mathrm{dl})]+11.2 \times \log ($ INR $)+9.6 \times \log$ [creatinine $(\mathrm{mg} / \mathrm{dl})]+6.4(10)$.

Ethical considerations. The ethics committee of the Infectious Disease Hospital of Fujian Medical University approved the present study. Written informed consent was obtained from all subjects.

Serological and HBV DNA assays. Non-heparinized arterial blood was centrifuged at $500 \mathrm{x} \mathrm{g}$ for $5 \mathrm{~min}$ at $20^{\circ} \mathrm{C}$ and stored at $-80^{\circ} \mathrm{C}$. Serum levels of HBsAg, hepatitis B virus surface antibody (anti-HBs), hepatitis B virus e antigen ( $\mathrm{HBeAg}$ ), hepatitis B virus e antibody (anti-HBe), hepatitis B virus core antibody (anti-HBc), anti-hepatitis A virus, anti-hepatitis $\mathrm{C}$ virus, anti-hepatitis $\mathrm{D}$ virus, anti-hepatitis $\mathrm{E}$ virus, and
anti-HIV antibodies were tested using AxSYMMEI kits according to the manufacturer's protocol (Abbott Laboratories, Abbott Park, IL, USA). The HBV DNA level was measured using a quantitative polymerase chain reaction (PCR) kit (cat. no. 041611; Triplex International Biosciences Co., Ltd., Fuzhou, China) with a detection limit $<420 \mathrm{IU} / \mathrm{ml}$. HBV DNA was extracted using silica-based technology as described by Boom et al (11). PCR was then performed on a STRATAGENE Mx3000P (Stratagene; Agilent Technologies, Inc., Santa Clara, CA, USA) instrument. Positive quality control, weak-positive quality control, negative quality control and 5 quantitative reference products $\left(1.0 \times 10^{3}, 1.0 \times 10^{4}, 1.0 \times 10^{5}, 1.0 \times 10^{6}\right.$ and $1.0 \times 10^{7} \mathrm{IU} / \mathrm{ml}$, respectively) were set. Three replicates were performed for each sample. The total PCR reaction volume was $50 \mu \mathrm{l}$ comprised of the following: $29 \mu \mathrm{l}$ PCR solution (containing primers, probe, $\mathrm{dN}(\mathrm{U}) \mathrm{TP}$ and other buffers), $1 \mu \mathrm{l}$ Taq DNA polymerase and $20 \mu \mathrm{l}$ purified DNA. The amplification was conducted as follows: Initial activation step at $37^{\circ} \mathrm{C}$ for $2 \mathrm{~min}$, initial hot start denaturation at $94^{\circ} \mathrm{C}$ for $2 \mathrm{~min}$, followed by 40 cycles of denaturation at $94^{\circ} \mathrm{C}$ for $15 \mathrm{sec}$ and annealing and extension at $55^{\circ} \mathrm{C}$ for $45 \mathrm{sec}$. The fluorescence was measured at the extension stage of each cycle. The quantification of DNA was calculated using the $2^{-\Delta \Delta C q}$ method (12). The quantitative analyses were performed by using STRATAGENE Mx3000P analysis software version 1.0 (Stratagene; Agilent) following the manufacturer's protocol. The sequences of the primers used were not provided with the kit.

Measurements of serum cytokine concentrations. Serum concentrations of cytokines (IL-1ra, IL-1 $\beta$, IL- 4 , IL-6, IFN- $\gamma$, IL-10, and TNF- $\alpha$ ) were measured using a Q-Plex multiplex array (cat. no. 104750GR; Quansys Biosciences, Logan, UT, USA) on a Q-View Imager (Quansys Biosciences) according to the manufacturer's protocol.

Incubation of peripheral blood mononuclear cells (PBMCs) with IL-Ira in vitro. PBMCs were isolated from the heparinized blood of 31 patients with ACLF via centrifugation at $800 \mathrm{x} \mathrm{g}$ at $20^{\circ} \mathrm{C}$ for 20 min using Ficoll Lymphoprep (Axis-Shield Diagnostics Ltd., Dundee, UK). Mononuclear cell bands were subsequently harvested using a Pasteur pipette and resuspended in PBS. Cells were centrifuged again at $650 \mathrm{x} g$ at $20^{\circ} \mathrm{C}$ for $10 \mathrm{~min}$, resuspended in PBS and centrifuged for a final time at $500 \mathrm{x}$ g at $20^{\circ} \mathrm{C}$ for $10 \mathrm{~min}$. Cells were resuspended in RPMI 1640 (Gibco; Thermo Fisher Scientific, Inc., Waltham, MA, USA) supplemented with 10\% FBS (Gibco; Thermo Fisher Scientific, Inc.). A total of $1 \times 10^{6}$ cells in $200 \mu$ l RPMI were subsequently seeded into 96-well plates and stimulated with PBS, lipopolysaccharide (LPS; Sigma-Aldrich; Merck KGaA, Darmstadt, Germany), LPS + $125 \mathrm{ng} / \mathrm{ml}$ recombinant human (rh) IL-1ra (ProSpec, East Brunswick, NJ, USA), LPS + $250 \mathrm{ng} / \mathrm{ml} \mathrm{rhIL}-1 \mathrm{ra}$, or LPS + $500 \mathrm{ng} / \mathrm{ml}$ rhIL-1ra. Cells were incubated for $24 \mathrm{~h}$ at $37^{\circ} \mathrm{C}$ in at atmosphere containing $5 \% \mathrm{CO}_{2}$ with $75 \%$ humidity, following which supernatants were collected and stored at $-80^{\circ} \mathrm{C}$ for uniform testing. The concentrations of IL-1 $\beta$, IL- 4 , IL-6, IL- 10 , IFN- $\gamma$, and TNF- $\alpha$ were measured as described above.

Statistical analysis. All data were analyzed using SPSS 13.0 (SPSS, Inc., Chicago, IL, USA). Data are expressed as the 
Table I. Clinical characteristics between groups.

\begin{tabular}{|c|c|c|c|c|c|}
\hline Characteristic & HB-ACLF $(n=31)$ & AHB $(n=28)$ & CHB $(n=31)$ & $\mathrm{HC}(\mathrm{n}=15)$ & P-value \\
\hline Gender $(\mathrm{M} / \mathrm{F})$ & $25 / 6$ & $23 / 5$ & $26 / 5$ & $12 / 3$ & 0.985 \\
\hline Age (years) & $36(23-46)$ & $33(19-45)$ & $36(20-48)$ & $33(19-45)$ & 0.103 \\
\hline $\mathrm{HBe} \mathrm{Ag}(\mathrm{Pos} / \mathrm{Neg})$ & $24 / 7$ & $22 / 6$ & $23 / 8$ & - & 0.152 \\
\hline $\begin{array}{l}\text { HBVDNA } \\
\left(\log _{10} \text { copies } / \mathrm{ml}\right)\end{array}$ & $6.45(2.66-8)$ & $5.37(3.08-7.95)$ & $7.34(4.68-9.95)$ & - & $<0.001$ \\
\hline Albumin (g/l) & $30(18-39)$ & $37(30-42)$ & $35(29-42)$ & $38(35-42)$ & $<0.001$ \\
\hline Bilirubin $(\mu \mathrm{M})$ & $372.30(216.80-702.90)$ & $106.03(29.60-311.00)$ & $33.90(8.09-241.00)$ & $13.90(7.00-27.03)$ & $<0.001$ \\
\hline $\operatorname{ALT}(\mathrm{U} / \mathrm{l})$ & $571(50-2554)$ & $570(105-2013)$ & $230(35-1202)$ & $13(7-32)$ & $<0.001$ \\
\hline PTA $(\%)$ & $28(12-40)$ & $81(50-118)$ & $80(54-120)$ & $99(80-124)$ & $<0.001$ \\
\hline
\end{tabular}

Quantitative variables are presented as the median (range). Categorical variables are presented as counts. Bold text indicates a statistically significant difference. HB-ACLF, hepatitis B-related acute-on-chronic liver failure; AHB, acute hepatitis B; CHB, chronic hepatitis B; HC, healthy control; Pos, positive; Neg, negative; ALT, alanine aminotransferase; PTA, prothrombin time activity.

Table II. Comparisons of serum cytokines in the four groups.

\begin{tabular}{lcccc}
\hline Cytokine & HB-ACLF & AHB & CHB & HC \\
\hline IL-1 ra & $186.46(350.22)^{\mathrm{a}-\mathrm{c}}$ & $143.69(90.79)^{\mathrm{b}, \mathrm{c}}$ & $70.47(45.40)^{\mathrm{c}}$ & $33.82(26.99)$ \\
IL-1 $\beta$ & $62.00(66.50)^{\mathrm{a}-\mathrm{c}}$ & $36.08(41.44)^{\mathrm{c}}$ & $31.85(18.77)^{\mathrm{c}}$ & $10.40(7.06)$ \\
IL-4 & $4.11(1.26)$ & $3.47(2.18)$ & $3.2(0.81)$ & $3.88(2.33)$ \\
IL-6 & $234.26(210.91)^{\mathrm{a}-\mathrm{c}}$ & $158.51(147.19)^{\mathrm{b}, \mathrm{c}}$ & $20.34(39.05)^{\mathrm{c}}$ & $9.23(1.31)$ \\
IFN- $\gamma$ & $46.12(23.58)^{\mathrm{c}}$ & $41.35(25.71)$ & $36.49(39.15)$ & $26.55(29.03)$ \\
IL-10 & $8.18(2.92)^{\mathrm{c}}$ & $8.23(3.48)^{\mathrm{c}}$ & $8.78(3.40)^{\mathrm{c}}$ & $5.52(3.12)$ \\
TNF- $\alpha$ & $30.97(26.77)^{\mathrm{a}-\mathrm{c}}$ & $21.11(7.03)^{\mathrm{c}}$ & $22.88(6.63)^{\mathrm{c}}$ & $10.65(5.79)$ \\
\hline
\end{tabular}

Datas are presented as median (interquartile range). ${ }^{\mathrm{a}} \mathrm{P}<0.01 \mathrm{vs}$. $\mathrm{AHB}$ group, ${ }^{\mathrm{b}} \mathrm{P}<0.01$ vs. $\mathrm{CHB}$ group, ${ }^{\mathrm{c}} \mathrm{P}<0.001$ vs. $\mathrm{HC}$ group. HB-ACLF, hepatitis B-related acute-on-chronic liver failure; AHB, acute hepatitis B; CHB, chronic hepatitis B; HC, healthy control; IL, interleukin; ra, receptor antagonist; IFN, interferon; TNF, tumor necrosis factor.

medians (interquartile range) or mean \pm standard deviation. Continuous variables were analyzed using the Kruskal-Wallis H-test, or Mann-Whitney U-test. Fisher's exact test was used for interclass comparisons of categorical variables. Statistical associations between variables were assessed using the Spearman rank order correlation coefficient. $\mathrm{P}<0.05$ was considered to indicate a statistically significant difference.

\section{Results}

Serum cytokine concentrations. Comparisons of serum cytokine concentrations in each group are presented in Table II. The serum levels of IL-1ra in the HB-ACLF group were 186.46 (350.22) $\mathrm{pg} / \mathrm{ml}$, which were significantly higher compared with the AHB $(\mathrm{P}<0.01), \mathrm{CHB}(\mathrm{P}<0.001)$, and $\mathrm{HC}(\mathrm{P}<0.001)$ groups. Serum concentrations of IL-1 $\beta$ [62 (66.5) pg/ml], IL-6 [234.26 (210.91) pg/ml], and TNF- $\alpha$ [30.97 (26.77) pg/ml] were also found to be significantly higher in the HB-ACLF group compared with all other groups (all $\mathrm{P}<0.01$ ). There were no significant differences in the serum concentrations of IL-4, IL-10, or IFN- $\gamma$ between the ACLF and AHB groups. Compared with the CHB group, the mean levels of IL-1ra,

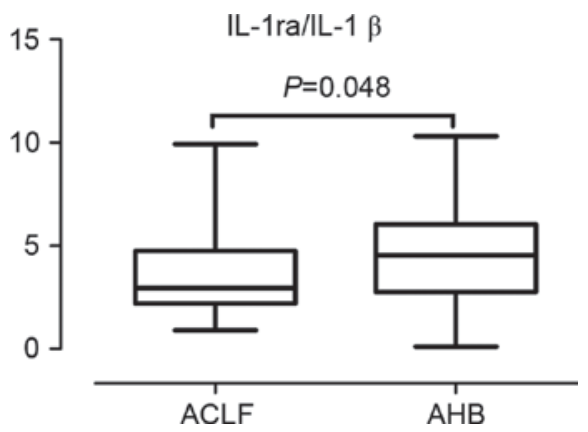

Figure 1. Ratio of IL-1ra to IL-1 $\beta$ in HB-ACLF and AHB patients. The ratio of IL-1ra to IL-1 $\beta$ was significantly different between the HB-ACLF and AHB groups $(\mathrm{P}=0.048)$. IL, interleukin; HB-ACLF, hepatitis B-related acute-on-chronic liver failure; $\mathrm{AHB}$, acute hepatitis $\mathrm{B}$; ra, receptor antagonist.

IL-1 $\beta$ and IL-6TNF- $\alpha$ in the HB-ACLF group, and the levels of IL-1ra and IL-6 in the AHB group were significantly higher (all $\mathrm{P}<0.01$ ). The ratio of IL-1ra to IL-1 $\beta$ was significantly lower in the HB-ACLF group at 2.96 (2.54) compared with in the AHB group at 4.54 (3.29; $\mathrm{P}=0.048 ;$ Fig. 1$)$. 
Table III. Clinical characteristics in survivor and non-survivor patients with HB-ACLF.

\begin{tabular}{lcccccccccc}
\hline Group & $\begin{array}{c}\text { Gender } \\
(\mathrm{M} / \mathrm{F})\end{array}$ & $\begin{array}{c}\text { Age } \\
(\mathrm{y})\end{array}$ & $\begin{array}{c}\text { HBeAg } \\
(+/-)\end{array}$ & $\begin{array}{c}\text { HBV-DNA } \\
\text { Log(copies/ml })\end{array}$ & $\begin{array}{c}\text { ALB } \\
(\mathrm{g} / \mathrm{l})\end{array}$ & $\begin{array}{c}\text { TBIL } \\
(\mu \mathrm{M})\end{array}$ & $\begin{array}{c}\text { ALT } \\
(\mathrm{U} / \mathrm{l})\end{array}$ & $\begin{array}{c}\text { PTA } \\
(\%)\end{array}$ & $\begin{array}{c}\text { ALPT } \\
(\mathrm{Y} / \mathrm{N})\end{array}$ & $\begin{array}{c}\text { AT } \\
(\mathrm{Y} / \mathrm{N})\end{array}$ \\
\hline Survivor & $15 / 4$ & $35(8)$ & $15 / 4$ & $6.1(3)$ & $28(9)$ & $465(194)$ & $562(719)$ & $24(14)$ & $16 / 3$ & $19 / 0$ \\
Non-survivor & $9 / 3$ & $37(7)$ & $10 / 2$ & $6.6(1.6)$ & $32(4)$ & $299(55)$ & $785(880)$ & $34(10)$ & $10 / 2$ & $12 / 0$ \\
P-value & 0.763 & 0.745 & 0.531 & 0.700 & $\mathbf{0 . 0 2 9}$ & $\mathbf{0 . 0 2 1}$ & 0.330 & $\mathbf{0 . 0 0 4}$ & 0.984 & - \\
\hline
\end{tabular}

Quantitative variables are presented as median (interquartile range). Categorical variables are presented as counts. Bold text indicated a statistically significant difference. HB-ACLF, hepatitis B-related acute-on-chronic liver failure; M, male; F, female; y, years; HBeAg, hepatitis B virus e antigen; HBV, hepatitis B virus; ALT, alanine aminotransferase; +, positive; -, negative; ALB, albumin; TBIL, total bilirubin; PTA, prothrombin time activity; Y, yes; N, No; ALPT, artificial liver support therapies; AT, antiviral therapies.
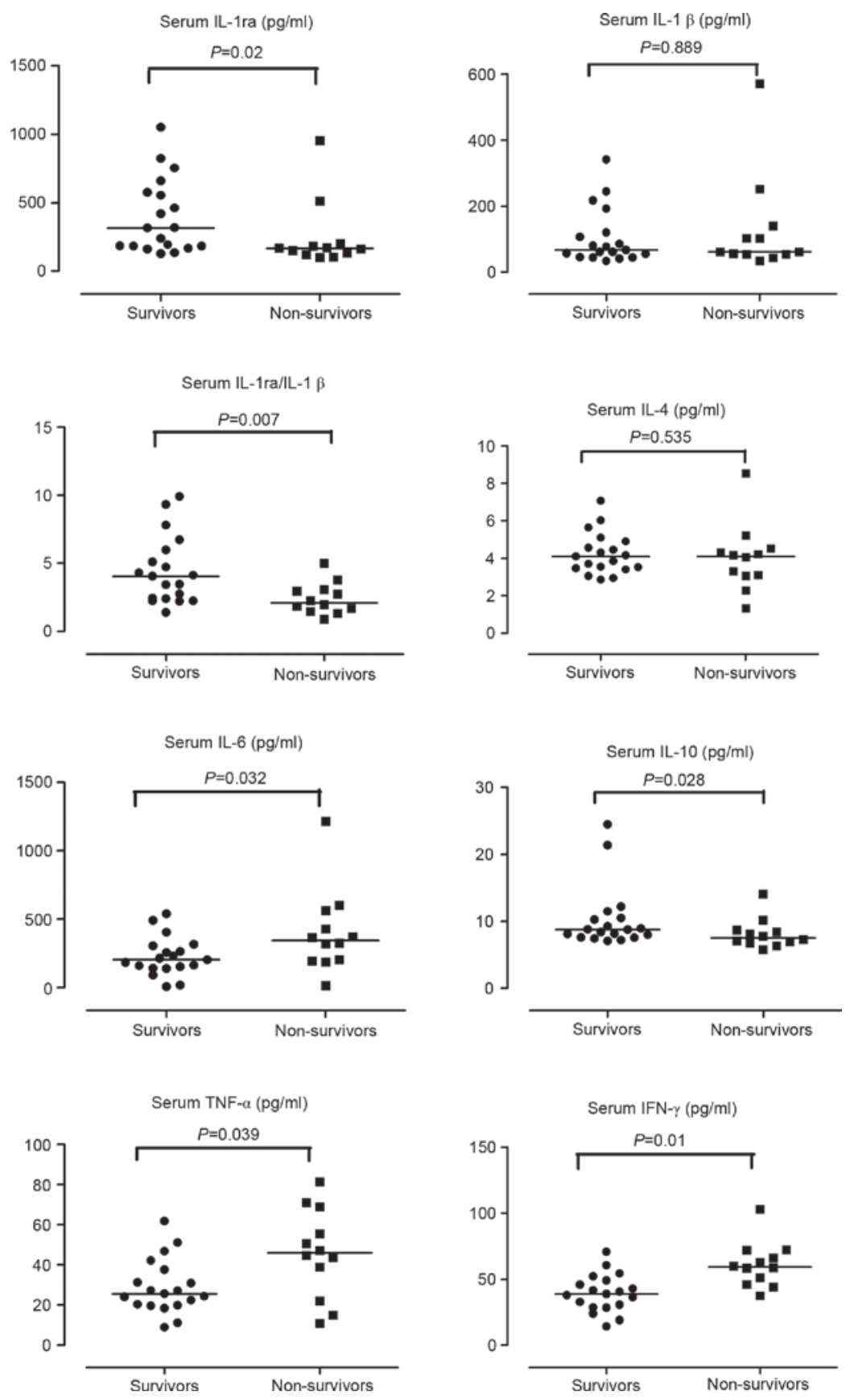

Figure 2. Associations between serum IL-1ra and clinical outcomes. Horizontal bars indicate the median values in each group. P-values indicate the significance between groups as determined via a Mann-Whitney U Test. IL, interleukin; ra, receptor antagonist; HB-ACLF, hepatitis B-related acute-on-chronic liver failure; survivors, surviving patients in HB-ACLF group; Non-survivors, deceased patients in HB-ACLF group; TNF, tumor necrosis factor; IFN, interferon. 

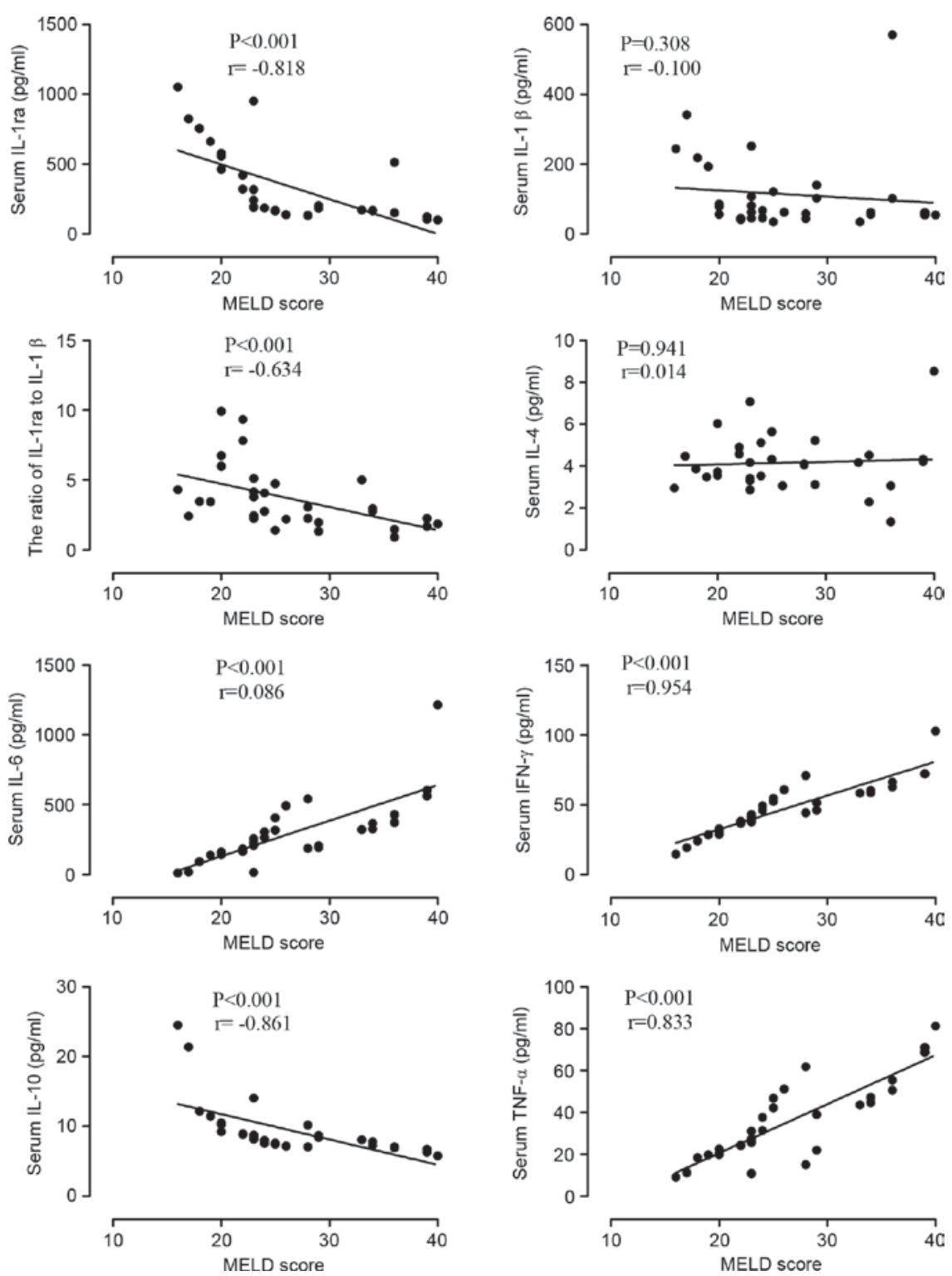

Figure 3. Correlation between serum cytokine levels and MELD score. The serum levels of IL-1ra, IL-1ra/IL-1 $\beta$ and IL-10 were negatively associated with MELD score (all P<0.001). The serum levels of IL-6, IFN- $\gamma$ and TNF- $\alpha$ were positively associated with MELD score (all P<0.001).There was no correlation between serum levels of IL-1 $\beta$ or IL-4 and MELD score. MELD, Model for End-stage Liver Disease; IL, interleukin; ra, receptor antagonist; IFN, interferon; $\mathrm{TNF}$, tumor necrosis factor.

Associations between IL-Ira and clinical outcomes. A total of 31 patients with HB-ACLF were subdivided into surviving $(\mathrm{n}=19)$ and deceased $(\mathrm{n}=12)$ groups (Table III). Serum concentrations of IL-1ra were significantly lower in the deceased ACLF group at 166.8 (71.53) $\mathrm{pg} / \mathrm{ml}$ compared with the surviving group at $317.27(92.08) \mathrm{pg} / \mathrm{ml}(\mathrm{P}=0.02)$. The ratio of IL-1ra to IL-1 $\beta$ was also lower in the deceased group [2.11 (1.51)] compared with the surviving group [4.06 (3.58); $\mathrm{P}=0.007]$. Furthermore, the deceased group were found to have significantly higher levels of IL-6 ( $\mathrm{P}=0.032)$, IFN- $\gamma$ $(\mathrm{P}=0.01)$, and TNF- $\alpha(\mathrm{P}=0.039)$, and lower levels of IL-10 $(\mathrm{P}=0.028)$ compared with the surviving group However, no significant differences were observed in IL-4 and IL-1 $\beta$ levels between the two groups (Fig. 2).

Associations between IL-1ra and severity of $H B-A C L F$. The results of the present study revealed an inverse relationship between the MELD score and serum levels of IL-1ra ( $\mathrm{r}=-0.818$; $\mathrm{P}<0.001)$ IL-1ra/IL-1 $\beta$ ( $\mathrm{r}=-0.634 ; \mathrm{P}<0.001)$, and IL-10 $(\mathrm{r}=-0.861 ; \mathrm{P}<0.001)$. Conversely, MELD scores were positively associated with serum levels of IL-6 ( $\mathrm{r}=0.086 ; \mathrm{P}<0.001)$, IFN- $\gamma$ $(r=0.954 ; \mathrm{P}<0.001)$, and TNF- $\alpha(r=0.833 ; \mathrm{P}<0.001$; Fig. 3$)$.

Associations between IL-1ra and HBV DNA and liver function. IL-1ra was demonstrated to be negatively associated with TBIL ( $\mathrm{r}=-0.506 ; \mathrm{P}=0.0004$ ) and positively associated with PTA $(\mathrm{r}=0.475 ; \mathrm{P}=0.007)$. However, IL-1ra was not associated with ALT, aspartate aminotransferase, ALB, or HBV DNA (Fig. 4).

Associations between IL-1ra and other cytokines. Serum IL-1ra levels were positively correlated $(n=105)$ with serum levels of IL-1 $\beta$ ( $r=0.766 ; \mathrm{P}<0.001)$, IL-6 ( $\mathrm{r}=0.506 ; \mathrm{P}<0.001)$, IL-10 ( $\mathrm{r}=0.40 ; \mathrm{P}<0.001)$, and TNF- $\alpha(\mathrm{r}=0.277 ; \mathrm{P}=0.004)$, but not with levels of IFN- $\gamma$ or IL-4 (Fig. 5). 

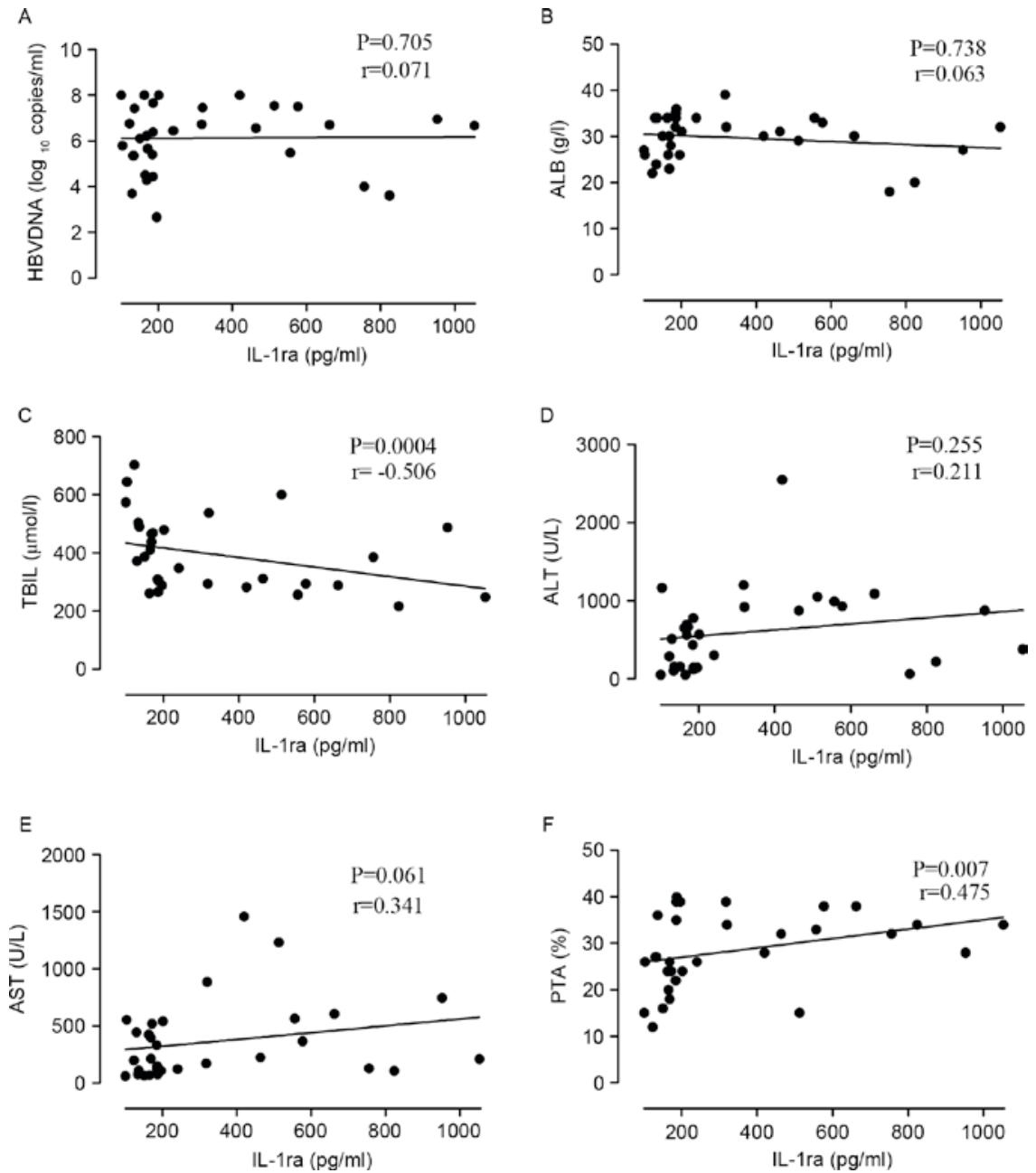

Figure 4. Spearman correlation coefficient between IL-1ra and (A) HBV DNA or (B-F) liver function measures. IL-1ra was negatively associated with TBIL $(\mathrm{P}=0.0004)$ and positively associated with PTA $(\mathrm{P}=0.007)$. IL, interleukin; ra, receptor antagonist; HBV, hepatitis B virus; TBIL, total bilirubin; PTA, prothrombin time activity; ALB, albumin; ALT, alanine aminotransferase; AST, glutamic oxalacetic transaminase.

Inhibition of cytokine secretion in LPS-stimulated PBMCs by rhIL-1ra. The concentrations of cytokines secreted by PBMCs from patients with HB-ACLF are presented in Fig. 6. A significant increase in the levels of 6 cytokines was detected following LPS stimulation of PBMCs compared with the PBS group (all $\mathrm{P}<0.001)$. A significant decrease was observed in levels of IL-1 $\beta(\mathrm{P}=0.001)$, IL-6 $(\mathrm{P}<0.001)$, IL-10 $(\mathrm{P}=0.018)$, IFN- $\gamma(\mathrm{P}=0.036)$, and TNF- $\alpha(\mathrm{P}=0.03)$ following the addition of rhIL-1ra compared with the LPS group. As expected, the inhibitory effects of IL-1ra occurred in a dose-dependent manner. However, no significant differences in IL-4 levels were observed among groups. This outcome was consistent with the serum findings (Fig. 6).

\section{Discussion}

The results of the present study demonstrated that concentrations of four cytokines (IL-1ra, IL-1 $\beta$, IL-6 and TNF- $\alpha$ ) were increased significantly in patients with HB-ALCF compared with the AHB and CHB groups. However, the ratio of IL-1ra to IL-1 $\beta$ was lower in the HB-ACLF group compared with the AHB group. Notably, serum IL-1ra concentration was negatively associated with MELD score. IL-1ra concentrations and the ratio of IL-1ra/IL-1 $\beta$ in the deceased group were significantly lower than that in the surviving group. In vitro, cytokine secretion by $\mathrm{PBMCs}$ was significantly inhibited in a dose-dependent manner by rhIL-1ra treatment. This suggests that IL-1ra serves an important role in the development of liver inflammation, which is relatively reduced in patients with HB-ACLF and inversely associated with disease severity. The results of the present study are in accordance with the observation of Hope et al (13) that IL-1Ra is associated with disease severity in mental illness.

Previous studies have established that an inflammatory environment is a key determinant in the progression of liver failure $(14,15)$. The pro-inflammatory cytokine IL-1 has a key role in regulating inflammatory and immune responses $(16,17)$. IL-1ra, a natural IL-1 antagonist acts via competitive inhibition without triggering a signaling cascade to reduce inflammation (18). Imbalances between IL-1 and IL-1ra are observed in many inflammatory disorders $(5,19,20)$, which is consistent with the results of the present study. Although serum IL-1ra concentration was higher in patients with HB-ACLF compared with patients with AHB, IL-1ra/IL-1 $\beta$ was lower. This suggests that endogenous IL-1ra was insufficient to antagonize the action of IL-1, resulting in a cascade of inflammation, which led to liver damage. 

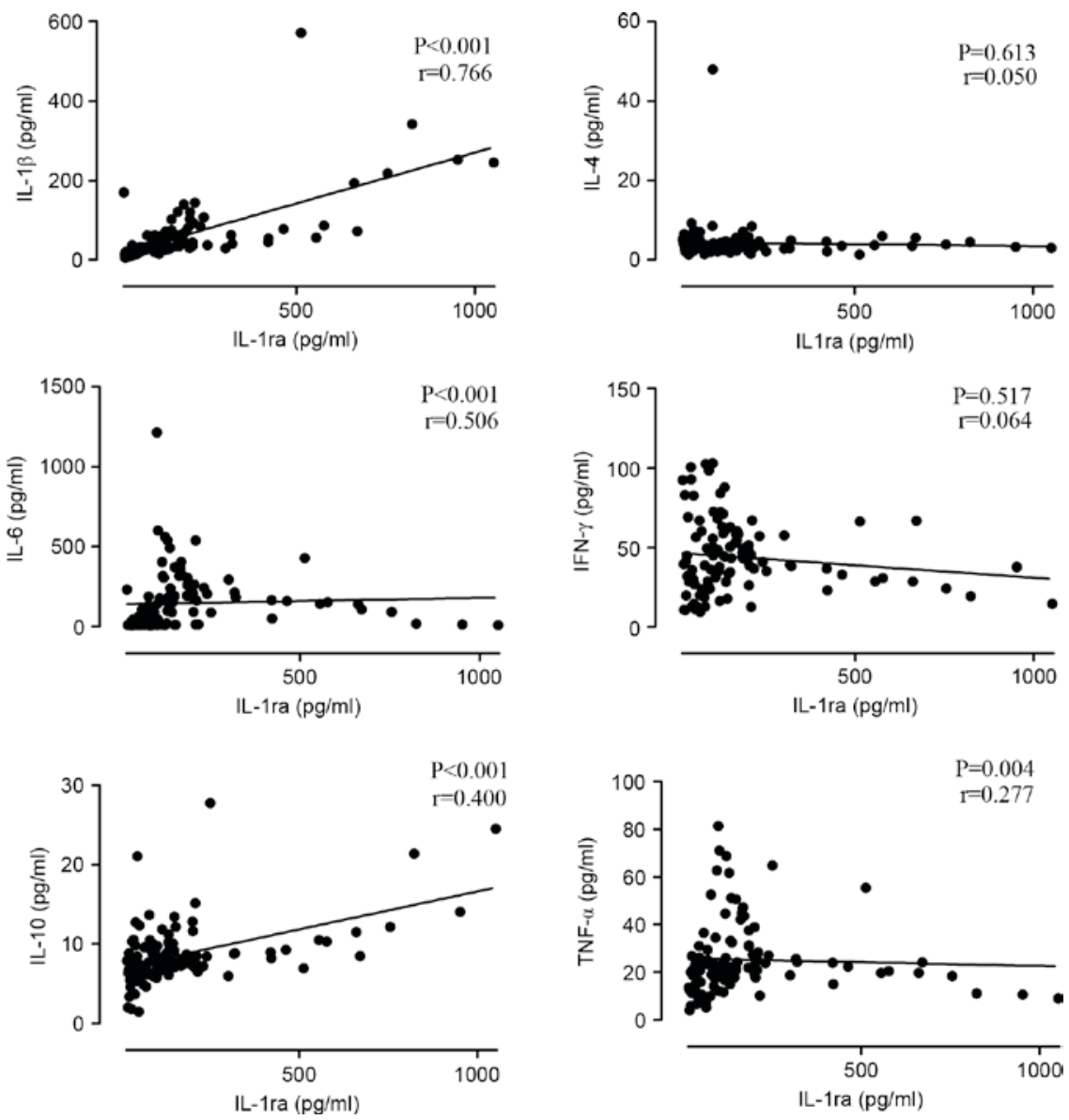

Figure 5. Association between IL-1ra and other cytokines. Serum IL-1ra levels were correlated with serum levels of IL-1 $\beta$ (P<0.001), IL-6 (P<0.001), IL-10 $(\mathrm{P}<0.001)$ and TNF- $\alpha(\mathrm{P}=0.004)$. IL, interleukin; ra, receptor antagonist; TNF, tumor necrosis factor; IFN, interferon.

IL-1ra is expressed by various immune cells including monocytes, macrophages, and $\mathrm{T}$ cells, as well as by nonimmune cells $(13,21)$. It has an anti-inflammatory effect, which is achieved via various pathways. When IL- $1 \beta$ induces the dimerization of IL-1 receptor accessory protein (IL-1RAcP) with IL-1-receptor type 1 (IL-1R1) to produce and release inflammatory cytokines, IL-1ra is able to prevent the recruitment of IL-1RAcP to regulate the inflammatory response (5). IL-1ra also blocks the biological activity of IL-1 by competitively binding to the IL-1 type I receptor (IL-1RI), which is expressed by various tissues (4). Additionally, it has been reported that IL-1ra is able to control the activation and migration of dendritic cells, thereby affecting local immune responses (22). IL-1ra also has anti-apoptotic roles in both acute and chronic inflammation, and is able to promote hepatocyte proliferation (6). A previous study suggested a potential role for IL-1ra in hepatocyte proliferation via promoting cell cycle transition from G1 to S phase (23). rhIL-1ra has been shown to have therapeutic effects in various inflammatory and autoimmune conditions mediated by the pathophysiological effects of IL-1 (24-29) in a dose-dependent manner.

In order to further investigate the role of IL-1ra in HB-ACLF, PBMCs were isolated from patients with HB-ACLF and incubated with various concentration of rhIL-1ra in vitro. The results revealed that rhIL-1ra induced the expression of anti-inflammatory cytokines, such as IL-10 and IL-4, and also reduced the production of pro-inflammatory cytokines, such as IFN- $\gamma$, IL-1, and IL-6. Furthermore, this inhibitory effect occurred in a dose-dependent manner. These results were in accordance with the observation of Petrasek et al (30) that administration of IL-1Ra dose-dependently ameliorated alcohol-induced liver steatosis and decreased levels of IL-1, TNF- $\alpha$ and MCP-1 in the serum of wild type mice injected with $1.5,10$, or $25 \mathrm{mg} / \mathrm{kg}$ IL-1Ra daily.

Notably, serum concentrations of IL-1ra appeared to be correlated with gender. The findings of the present study demonstrated that serum levels of IL-1ra in female patients with ACLF were significantly higher than those in males. These observations are consistent with those of Stosić-Grujicić (31), who reported that peripheral monocytes obtained from women during the menstrual cycle produced 5-10 times more IL-1ra than cells from men. A possible explanation for this difference may be a difference in IL-1RN between female and male patients. Tountas et al (32) reported that the IL1RNVNTR A2 allele has been associated with reduced levels of IL-1ra.

There were several limitations to the present study. Patients with moderate $\mathrm{CHB}$ were not distinguished from those with severe $\mathrm{CHB}$, as the latter has been associated with a relatively better prognosis than ACLF, but is much more severe than that of moderate CHB $(26,33)$. Furthermore, markers were only measured at one time point for some patients who received plasma exchange, which may have influenced cytokine measurements. Markers in the liver were not characterized due 

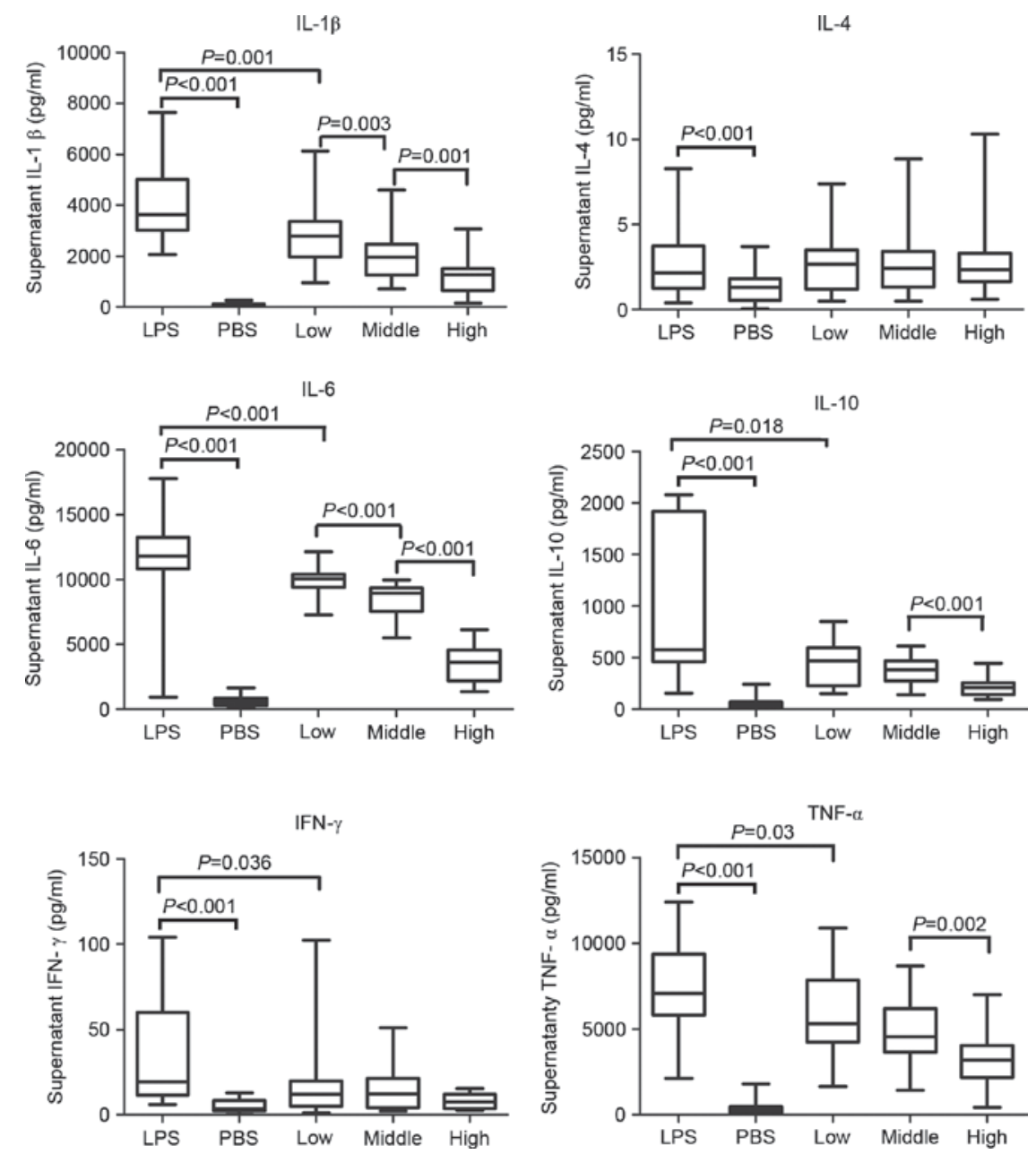

Figure 6. Inhibition of cytokine secretion in LPS-stimulated PBMCs by rhIL-1ra. LPS, lipopolysaccharide; PBMCs, peripheral blood mononuclear cells; rh, human recombinant; IL, interleukin; ra, receptor antagonist; low, LPS + $125 \mathrm{ng} / \mathrm{ml} \mathrm{rhIL-1ra;} \mathrm{middle,} \mathrm{LPS} \mathrm{+} 250 \mathrm{ng} / \mathrm{ml} \mathrm{rhIL}-1 \mathrm{ra}$; high, LPS + 500 ng/ml rhIL-1ra; IFN, interferon; TNF, tumor necrosis factor.

to the poor condition of patients with HB-ACLF, making them unsuitable for liver biopsy.

Collectively, although serum levels of IL-1ra in patients with HB-ACLF increased significantly due to the activation of IL-1, the ratio of IL-1ra/IL- $1 \beta$ was lower in the HB-ACLF group compared with the AHB group. This suggests that IL-1 signaling in the liver is subject to tight endogenous control, and endogenous IL-1ra is insufficient to neutralize the effects of IL-1 in patients with HB-ACLF. Additionally, lower IL-1ra concentrations were demonstrated to be associated with increased disease severity and poor survival in patients with HB-ACLF. PBMCs from patients with HB-ACLF treated with IL-1ra are able to regulate immune disorders. The present study indicates that immune activation has a role in the core pathological mechanisms of HB-ACLF. The underlying mechanisms, including the potential impact of IL-1ra on HB-ACLF severity and the clinical significance of immune suppression, remain to be elucidated and require further evaluation in larger studies.

\section{Acknowledgements}

The present study was supported by grants from the Planned Science And Technology Project of Fuzhou of China (grant no. 2013-S-125-3), Education Fund for Youth Teachers of Fujian Province (grant no. JB13126), and the Youth Scientific Research Fund of the Fujian Health and Family Planning Commission, China (grant no. 2013-2-82).

\section{References}

1. Cao GW: Clinical relevance and public health significance of hepatitis B virus genomic variations. World J Gastroenterol 15: 5761-5769, 2009.

2. Sheng YJ, Liu JY, Tong SW, Hu HD, Zhang DZ, Hu P and Ren H: Lamivudine plus adefovir combination therapy versus entecavir monotherapy for lamivudine-resistant chronic hepatitis B: A systematic review and meta-analysis. Virol J 8: 393, 2011.

3. Sarin SK, Kedarisetty CK, Abbas Z, Amarapurkar D, Bihari C, Chan AC, Chawla YK, Dokmeci AK, Garg H, Ghazinyan H, et al: Acute-on-chronic liver failure: Consensus recommendations of the asian pacific association for the study of the liver (APASL) 2014. Hepatol Int 8: 453-471, 2014.

4. Krumm B, Xiang Y and Deng J: Structural biology of the IL-1 superfamily: Key cytokines in the regulation of immune and inflammatory responses. Protein Sci 23: 526-538, 2014.

5. Moll M and Kuemmerle-Deschner JB: Inflammasome and cytokine blocking strategies in autoinflammatory disorders. Clin Immunol 147: 242-275, 2013.

6. Zheng YB, Zhang XH, Huang ZL, Lin CS, Lai J, Gu YR, Lin BL Xie DY, Xie SB, Peng L and Gao ZL: Amniotic-fluid-derived mesenchymal stem cells overexpressing interleukin-1 receptor antagonist improve fulminant hepatic failure. PLoS One 7: e41392, 2012. 
7. Liu Q: Role of cytokines in the pathophysiology of acute-on-chronic liver failure. Blood Purif 28: 331-341, 2009.

8. National Institute for Health and Clinical Excellence (NICE): Hepatitis B (Chronic): diagnosis and management. https://www. nice.org.uk/guidance/cg165. Accessed June, 2013.

9. Sarin SK, Kedarisetty CK, Abbas Z, Amarapurkar D, Bihari C, Chan AC, Chawla YK, Dokmeci AK, Garg H, Ghazinyan H, et al: Acute-on-chronic liver failure: Consensus recommendations of the asian pacific association for the study of the liver (APASL) 2014. Hepatol Int 8: 453-471, 2014.

10. Wang DW, Yin YM and Yao YM: Advances in the management of acute liver failure. World J Gastroenterol 19: 7069-7077, 2013

11. Boom R, Sol CJ, Heijtink R, Wertheim-van Dillen PM and van der Noordaa J: Rapid purification of hepatitis B virus DNA from serum. J Clin Microbiol 29: 1804-1811, 1991.

12. Livak KJ and Schmittgen TD: Analysis of relative gene expression data using real-time quantitative PCR and the 2(-Delta Delta C(T)) method. Methods 25: 402-408, 2001.

13. Hope S, Ueland T, Steen NE, Dieset I, Lorentzen S, Berg AO, Agartz I, Aukrust P and Andreassen OA: Interleukin 1 receptor antagonist and soluble tumor necrosis factor receptor 1 are associated with general severity and psychotic symptoms in schizophrenia and bipolar disorder. Schizophr Res 145: 36-42, 2013.

14. Bode JG, Albrecht U, Haussinger D, Heinrich PC and Schaper F: Hepatic acute phase proteins-regulation by IL-6- and IL-1-type cytokines involving STAT3 and its crosstalk with NF- $\mathrm{BB}$-dependent signaling. Eur J Cell Biol 91: 496-505, 2012.

15. Jalan R, Gines P, Olson JC, Mookerjee RP, Moreau R, Garcia-Tsao G, Arroyo V and Kamath PS: Acute-on chronic liver failure. J Hepatol 57: 1336-1348, 2012.

16. Vollmar B and Menger MD: The hepatic microcirculation: Mechanistic contributions and therapeutic targets in liver injury and repair. Physiol Rev 89: 1269-1339, 2009

17. Shi XL, Zhu W, Tan JJ, Xiao JQ, Zhang L, Xu Q, Ma ZL and Ding YT: Effect evaluation of interleukin-1 receptor antagonist nanoparticles for mesenchymal stem cell transplantation. World J Gastroenterol 19: 1984-1991, 2013.

18. Dinarello CA, Simon A and van der Meer JW: Treating inflammation by blocking interleukin-1 in a broad spectrum of diseases. Nat Rev Drug Discov 11: 633-652, 2012.

19. Smith CJ, Emsley HC, Udeh CT, Vail A, Hoadley ME, Rothwell NJ, Tyrrell PJ and Hopkins SJ: Interleukin-1 receptor antagonist reverses stroke-associated peripheral immune suppression. Cytokine 58: 384-389, 2012.

20. Uludag IF, Bilgin S, Zorlu Y, Tuna G and Kirkali G: Interleukin-6, interleukin-1 beta and interleukin-1 receptor antagonist levels in epileptic seizures. Seizure 22: 457-461, 2013.

21. Dinarello CA: Immunological and inflammatory functions of the interleukin-1 family. Annu Rev Immunol 27: 519-550, 2009.
22. Iizasa $\mathrm{H}$, Yoneyama $\mathrm{H}$, Mukaida N, Katakoka Y, Naito $\mathbf{M}$, Yoshida N, Nakashima E and Matsushima K: Exacerbation of granuloma formation in IL-1 receptor antagonist-deficient mice with impaired dendritic cell maturation associated with Th2 cytokine production. J Immunol 174: 3273-3280, 2005.

23. Sgroi A, Gonelle-Gispert C, Morel P, Baertschiger RM, Niclauss N, Mentha G, Majno P, Serre-Beinier V and Buhler L: Interleukin-1 receptor antagonist modulates the early phase of liver regeneration after partial hepatectomy in mice. PLoS One 6: e25442, 2011.

24. Bodar EJ, Kuijk LM, Drenth JP, van der Meer JW, Simon A and Frenkel J: On-demand anakinra treatment is effective in mevalonate kinase deficiency. Ann Rheum Dis 70: 2155-2158, 2011.

25. Hedrich CM, Bruck N, Fiebig B and Gahr M: Anakinra: A safe and effective first-line treatment in systemic onset juvenile idiopathic arthritis (SoJIA). Rheumatol Int 32: 3525-3530, 2012.

26. Hu X, Ma S, Huang X, Jiang X, Zhu X, Gao H, Xu M, Sun J, Abbott WG and Hou J: Interleukin-21 is upregulated in hepatitis B-related acute-on-chronic liver failure and associated with severity of liver disease. J Viral Hepat 18: 458-467, 2011.

27. Kuemmerle-Deschner JB, Tyrrell PN, Koetter I, Wittkowski H, Bialkowski A, Tzaribachev N, Lohse P, Koitchev A, Deuter C, Foell D and Benseler SM: Efficacy and safety of anakinra therapy in pediatric and adult patients with the autoinflammatory Muckle-Wells syndrome. Arthritis Rheum 63: 840-849, 2011

28. Meinzer U, Quartier P, Alexandra JF, Hentgen V, Retornaz F and Koné-Paut I: Interleukin-1 targeting drugs in familial Mediterranean fever: A case series and a review of the literature. Semin Arthritis Rheum 41: 265-271, 2011

29. Obici L, Meini A, Cattalini M, Chicca S, Galliani M, Donadei S, Plebani A and Merlini G: Favourable and sustained response to anakinra in tumour necrosis factor receptor-associated periodic syndrome (TRAPS) with or without AA amyloidosis. Ann Rheum Dis 70: 1511-1512, 2011.

30. Petrasek J, Bala S, Csak T, Lippai D, Kodys K, Menashy V, Barrieau M, Min SY, Kurt-Jones EA and Szabo G: IL-1 receptor antagonist ameliorates inflammasome-dependent alcoholic steatohepatitis in mice. J Clin Invest 122: 3476-3489, 2012.

31. Stosić-Grujicić S and Lukić ML: Glucocorticoid-induced keratinocyte-derived interleukin-1 receptor antagonist(s). Immunology 75: 293-298, 1992

32. Tountas NA, Casini-Raggi V, Yang H, Di Giovine FS, Vecchi M, Kam L, Melani L, Pizarro TT, Rotter JI and Cominelli F: Functional and ethnic association of allele 2 of the interleukin-1 receptor antagonist gene in ulcerative colitis. Gastroenterology 117: 806-813, 1999.

33. Yang L, Ma S, Hu X, Xiao L, Wang Z, Li Y, Zhou B, Abbott WG and Hou J: Presence of valine at position 27 of the hepatitis B virus core gene is associated with severe liver inflammation in Chinese patients. J Med Virol 83: 218-224, 2011. 